\title{
Impact of FDI on Agricultural Sector: Evidence from Ivory Coast
}

\author{
Kouassi verena dominique $^{1^{*}} \quad \mathrm{Xu} \mathrm{Honyi}^{1} \quad$ Jean Baptiste Bernard Pea-Assounga ${ }^{2}$ \\ 1.School of Management, Wuhan University of Technology, Wuhan, Hubei, 430070, P.R. China \\ 2. School of Finance and Economics, Jiangsu University, Zhenjiang, Jiangsu, 212013, P.R. China
}

\begin{abstract}
This study examines the impact of Foreign Direct Investment (FDI) on the agricultural sector in Ivory Coast from 1990 to 2018. Phillips-Peron tests and augmented Dickey-Fuller tests were employed for a unit root in the variables. The Johansen Cointegration test and the VAR were used to estimate the stability and normality. VECM were used to analyze the short-term and the long-term dynamics. Results reveal that FDI has a negative and long run relationship but a significant effect in short-run on the agricultural sector.
\end{abstract}

Keywords: Agricultural Sector, FDI, Ivory Coast

DOI: $10.7176 / \mathrm{EJBM} / 13-15-04$

Publication date:August $31^{\text {st }} 2021$

\section{Introduction}

Foreign direct investment was not really accepted by the Ivorian government after the independence. It was seen as a slowdown for national companies and multinational companies were seen as a decelaration of social stability through the manipulation of price transfers. With globalization, Ivory Coast, has found itself forced to seek sources of investment in order to avoid putting the country in debt. This is how the country decided to move towards FDI as it is less impacted by financial crises and is more stable in term of investments. Foreign Direct Investment has generated billions in developing countries in several sectors of activity including agricultural sector for some countries. In order to solve their problems, African countries have decided to focus on the agricultural sector, which is an important area in FDI because FDI has contributed in the agricultural growth and this is important for the poverty reduction, food sufficiency and enhancing sustainability in the developing countries Msuya (2007). Klein, Aaron and Hadjimichael (2001); Blomström, Kokko and Mucchielli (2003); Borensztein, De Gregorio and Lee (1998) revealed that FDI take an important part in the economic growth's promotion and new employment creation in developing countries. In fact, FDI is a strategy that authorizes investing companies to keep share by readjusting their production nationally and internationally.

As reported by UNCTAD, countries in transition and developing countries are the principal destinations for FDI because they have attracted more than half-global FDI inflow. Romer (1993), Aitken and Harrison (1991) confirm that FDI generate job creation, technology transfer and quality of education in host countries.

However, reviews of existing literature talk more about the impact of FDI on economic growth in Cote d'Ivoire and do not really focus on agriculture. Since agriculture is important in the Ivorian economy, our article will go beyond these limitations. This article focus on the impact of agriculture on FDI.

In order to analyze the impact of Foreign Direct Investment on Ivorian agriculture, our study will be organized as follow: firstly we will discuss some literature, secondly the methodology and discussion, then the results and disccussion to finally make a conclusion about our work.

\section{Literature review}

Several empirical studies have attempted to assess the effect of FDI on economic growth and agriculture in developing countries. While some authors claim to have a positive relationship between FDI on growth and agriculture, other authors claim the opposite. In order to deepen our analysis, studies have been carried out to assess the positive impact of FDI on growth and agriculture and the negative impact that FDI has on growth and agriculture.

Yapatake, Li and Abeid (2017) carried out a study on the slow inflow and growth of FDI in the Cameroon over a period from 1996 to 2014. The result shows domestic credit to the private sector, gross domestic product growth, quality of public administration, and electricity productions are not statistically significant (at 0.05 level of significance).

In order to provide a supply, the authors suggested renovating the national electricity supply company with the aim of attracting FDI.

Dounamba (2016) in his research on the impact of Foreign Direct Investment on Economic Growth on underdeveloped African countries case of Mali, confirm a good relationship between FDI inflow and economic growth in Mali. Using a questionnaire from a group of 50 sample populations proved the study. Those people were 5 officials of World Bank, 5 people In Mali's Foreign Affairs ministry, 15 Malian Investors, 5 from the finance ministry, 10 universities professors and 5 economists.

On FDI and the agricultural sector, Edeh, Eze and Ugwuanyi (2020) using The Autoregressive Distributed 
Lagged (ARDL) model, Fully Modified Least Squares (FMOLS) and Dynamic Ordinary Least Squares (DOLS) to study Impact of foreign direct investment on the agricultural sector in Nigeria during the period 1981 to 2017. Their result revel that foreign direct investment has a positive and significant impact on agricultural sector output.

In the same vein, Awunyo and Sackey (2018) establish the relationship between foreign direct investment to Ghana's agriculture sector and economic growth by using descriptive statistic, unit root test, Granger causality test and error correction model. They found a positive and significant relationship between economic growth and FDI in the agricultural sector.

Although it has the positive impact of FDI on economic growth as postulated by economic theory, some empirical results tend to present either a negative or an ambiguous relationship between these variables.

Alfaro and Charlton (2007) observed an ambiguous effect of FDI on economic growth on cross-sectional data from 47 countries covering the period 1981 to 1999. Employing the Generalized system Method of Moments equations in his sectoral analysis, the study found a positive and ambiguous impact of FDI on manufacturing and service sectors growth while that of primary sector growth was seen to be negative.

Mazenda (2014) in his study on the effect on Foreign Direct Investment on economic growth: evidence of South Africa observes a negative impact on growth. His statement was proved by using johansen cointegratest test and error correction modeling (VECM).

In Ghana economy, Iddrisu, Immurana and Halidu (2015) researched on The Impact of Foreign Direct Investment (FDI) on the performance of the Agricultural Sector using VAR model they found negative impacts of FDI on the agricultural sector productivity in the long-run but with positive relationship in the short run.

Epaphra and Mwakalasya (2017) also found no significant effect of FDI on agricultural sector in Tanzania by using classical regression model and ordinary least square in their study.

\section{Methodology and Data Description}

A single cross-country time series is used in our study from 1990 to 2018. The different variables used for our different test are: TOP (Trade Openness), RER (Exchange Rate), INF (Inflation), ATFP (Agriculture Total Factor Productivity), FDI (Foreign Direct Investment), PK (Physical Capital), HK (Human Capital Development). The data are obtained from World Bank Development Indicator (Bank 2019)

In order to know the effect of agriculture on foreign direct investment, we used some models such as the Phillips-Peron and augmented Dickey-fuller tests. Subsequently, we used the Johansen Cointegration test and the VAR to estimate normality and stability. Finally, the VECM was used to analyze the short-term and long-term dynamics.

\section{Results and discussion}

In our study, we made discussions on the results and conclusions of the tests that we carried out in the first part. In the second part, we have analyses of the results from Phillips-Peron tests and the augmented Dickey-Fuller for a unit root within the study variables. The third section presents the results of the Johansen co-integration test and the VAR to demonstrate the long-term relationship between the variables chosen. Outcomes from assessments of diagnostic tests performed on the VAR have also been conducted to ensure stability and normalcy. Finally, our fourth section shows the analysis of the long-term dynamics of VECM.

In order to do a thorough study of the Unit Root tests, the Dicky-Fuller (ADF) and Philips-Peron (PP) tests were employed. The two tests have been performed at levels with trend, intercepts and neither trend nor intercepts. We aslso use the automatic lag selection by the Swartz info criterion. 
Table 1.Unit root results at level

\begin{tabular}{|l|l|c|c|}
\hline \multicolumn{4}{|c|}{ ADF } \\
\hline \multicolumn{1}{|c|}{ Variable } & Specification through DSR procedure & ADF 5\% Critical Value & ADF Stat \\
\hline ATFP & Trend and Constant & -4.4363 & -1.4368 \\
\hline FDI & Trend and Constant & -3.5806 & -0.4501 \\
\hline PK & Trend and Constant & -2.9718 & -0.5173 \\
\hline HK & Trend and Constant & -2.9718 & 1.1294 \\
\hline TOP & Trend and Constant & -2.9718 & -1.3299 \\
\hline RER & Trend and Constant & -3.8388 & -1.3663 \\
\hline INF & Trend and Constant & -1.9533 & -1.7360 \\
\hline \multicolumn{2}{|c|}{ PP } & \multicolumn{2}{c|}{} \\
\hline Variable & Specification through DSR procedure & PP 5\% Critical Value & PP Stat \\
\hline ATFP & Trend and Constant & -4.4343 & -1.4537 \\
\hline FDI & Trend and Constant & -2.9718 & -2.4113 \\
\hline PK & Trend and Constant & -2.9718 & -0.6658 \\
\hline HK & Trend and Constant & -2.9718 & 1.0836 \\
\hline TOP & Trend and Constant & -2.9718 & -1.4427 \\
\hline RER & Trend and Constant & -3.8647 & -1.3748 \\
\hline INF & Trend and Constant & -2.8373 & -1.6548 \\
\hline
\end{tabular}

Table 2. Unit root results at First Difference

\begin{tabular}{|l|l|c|c|}
\hline \multicolumn{4}{|c|}{ ADF } \\
\hline Variable & Specification through DSR procedure & ADF 5\% Critical Value & ADF Stat \\
\hline ATFP & Trend and Constant & -1.9486 & -5.3262 \\
\hline FDI & Trend and Constant & -2.9762 & -3.6552 \\
\hline PK & Trend and Constant & -2.9762 & -4.4951 \\
\hline HK & Trend and Constant & -1.9538 & -7.0216 \\
\hline TOP & Trend and Constant & -2.9762 & -4.6912 \\
\hline RER & Trend and Constant & -2.5373 & -4.4363 \\
\hline INF & Trend and Constant & -2.9718 & -3.7092 \\
\hline \multicolumn{2}{|c|}{ PP } & \multicolumn{2}{|c|}{} \\
\hline Variable & Specification through DSR procedure & PP 5\% Critical Value & PP Stat \\
\hline ATFP & Trend and Constant & -1.9648 & -5.3648 \\
\hline FDI & Trend and Constant & -2.9762 & -6.5582 \\
\hline PK & Trend and Constant & -2.9762 & -4.4971 \\
\hline HK & Trend and Constant & -2.9762 & -4.2177 \\
\hline TOP & Trend and Constant & -2.9762 & -4.6915 \\
\hline RER & Trend and Constant & -2.8377 & -4.3663 \\
\hline INF & Trend and Constant & -2.9718 & -3.7263 \\
\hline
\end{tabular}

In order to avoid the problem of spurious regression and make meaningful estimations, it is recommended to check the stationarity of the variable by using the unit root test.

In order to check for unit root or non-stationarity of the variables. The augmented Dicky Fuller and PhillipPerron test have been used.

In addition, subsequently we apply to difference if variables are found non-stationary. The results from Table 1 and table 2 indicate that the majority of variables are not stationary at levels but became stationary after differencing them. The co-integration can thus be used to evaluate the long-run relationship among variables.

\subsection{Vector Autoregressive (VAR) and Co-integration Analyses}

In our study, we used Johansen cointegration in order to demonstrate a long-term relationship. Thus, it is therefore necessary to characterize the optimal lag length of the VAR to perform the procedure. We used three models for this sector with the aim of knowing the impact of FDI on agricultural growth in Côte d'Ivoire. An estimation is required by the Johansen co-integration test.

In this model, the different variables ATFP (Agriculture Total Factor productivity), FDI (Foreign Direct Investment), PK (Physical Capital), HK (Human Capital Development), TOP (Trade Openness), RER (Exchange Rate) and INF (Inflation) are inserted as dependent variables, while a dummy variable is used as an exogenous variable in order to consider the structural breaks within the variables. 


\subsection{Diagnostic tests}

In order to confirm the reliability and adaptability of our VAR model, diagnostic tests were performed. The model was tested for stability, heteroskedasticity, serial correlation and normality so as not to have distorted results. It was necessary to perform the Lagrange multiplier (LM), the Jarque-Bera normality, the stability, and the White heteroskedasticity tests. Table 3 below gives us the results of our three tests and figure 1 gives us the stability graphs.

Table 3. Diagnostics Test Result

\begin{tabular}{|l|l|l|l|l|}
\hline Test & Null hypothesis & Model & t-statistic & Probability \\
\hline LM test & No serial correlation & Agriculture & 46.55 & 0.15 \\
\hline Jarque- Bera & There is a normal distribution & Agriculture & 26.38 & $\mathbf{0 . 3 2}$ \\
\hline White test & No conditional heteroscedasticity & Agriculture & 29.55 & 0.12 \\
\hline
\end{tabular}

The results of the Lagrange multiplier (LM) test indicated that at lag 12, there is an absence of serial correlations in the VARs estimated. The null hypothesis of no serial correlation was failed to be rejected because the probability was greater than 0.10 . The result of the Jarque-Bera test proved that the residues were distributed normally. This therefore confirms that the $\mathrm{p}$ values were high and more than 0.10 , indicating that the residuals have all been distributed normally and that the null hypothesis was not rejected.

The third test was the White (1980) test for heteroscedasticity in the absence of cross-terms.

All of the models confirmed that the errors' variance was constant along all observations and that the residuals were linear. We did not reject null because the p-values were acceptable over 0.05 . The last diagnostic test was the stability graph (figure 1) where the graphs proved that the lines lie inside the critical bandwidth, and none lines lay out of the band.

The conclusion we can draw according to the stability test is that the VARs have been well specified and stable. Cointegration was performed to verify a long-term relationship bamong the variables based on VAR diagnostic tests. Table 4 has analyzed and reported the results of Johansen cointegration.

\subsection{Johansen Cointegration Test Results}

Following the Johansen co-integration procedure, a long-run relationship between the variables has been performed using the estimated Vector Autoregressive (VAR) of the agricultural sector. Table 4 below shows the findings' summary of the co-integration tests.

Table 4: Agriculture sector co-integration results

\begin{tabular}{|c|c|c|c|c|c|}
\hline $\begin{array}{c}\text { Null hypothesis } \\
\text { H0 }\end{array}$ & Alternative H1 & Trace statistics & $\begin{array}{c}0.05 \% \text { critical } \\
\text { value }\end{array}$ & $\begin{array}{c}\text { Max-Eigen } \\
\text { statistics }\end{array}$ & $\begin{array}{c}0.05 \% \text { critical } \\
\text { values }\end{array}$ \\
\hline $\mathrm{R}=0$ & $\mathrm{R} \leq 1$ & $171.36^{*}$ & 102.73 & $77.926^{*}$ & 48.07 \\
\hline $\mathrm{R} \leq 1$ & $\mathrm{R} \leq 2$ & $122.39^{*}$ & 95.75 & $46.84^{*}$ & 40.08 \\
\hline $\mathrm{R} \leq 2$ & $\mathrm{R} \leq 3$ & $75.55^{*}$ & 69.82 & 30.94 & 33.88 \\
\hline $\mathrm{R} \leq 3$ & $\mathrm{R} \leq 4$ & 44.61 & 47.86 & 28.36 & 27.58 \\
\hline $\mathrm{R} \leq 4$ & $\mathrm{R} \leq 5$ & 16.24 & 29.80 & 11.68 & 21.13 \\
\hline $\mathrm{R} \leq 5$ & $\mathrm{R} \leq 6$ & 4.5 & 15.49 & 4.26 & 14.26 \\
\hline $\mathrm{R} \leq 6$ & $\mathrm{R} \leq 7$ & 0.31 & 3.84 & 0.30 & 3.84 \\
\hline
\end{tabular}

Source: Authors' computations via Eviews 10.

* indicates that the hypothesis was rejected at the level of 0.05 .

The result of the table shows that there is a long-run relationship. The models showed a linear deterministic trend and had been estimated assuming that the co-integration equation in the VAR had an intercept and no trend. The trace and Max-Eigen statistic tests were used concomitantly in the Johansen co-integration test. These two statistical tests may reveal different levels of co-integration between variables.

The agricultural model admitted three cointegration equations of the static trace two co-integration equations of the Max-Eigen statistics and three cointegration equations of the static trace. This study considered Max-Eigen value statics to estimate VECM because it has even more exact alternative hypotheses that determined the levels of co-integrated vectors (Enders, 2004). This enables the derivation of a long-run relationship between the variables and the estimation of a VECM model to determine the variable's long- and short-term dynamics.

\subsection{Long-run VECM Results}

After detecting cointegration between variables, the VECM model was identified. It defined long- and short-run relationships and then utilized coefficients to demonstrate the long-run effects of the various variables studied. To ensure that the parameters matrix converge after iterations, cointegration restrictions have been enforced on them. With the use of co-integration, at least one constraint on the long-run parameters had to be implemented. Consequently, the dependent variable ATFP were limited to 1 . The agricultural model had three restrictions, two 
short-run and one long-run. The model's constraints were binding and satisfied the condition of identifying rank. The short-run constraints were imposed as a result of the variables' insignificant effects on short-run adjustments. The table 5 shows a summary of the long-run parameters.

\subsection{FDI and TFP in the Agricultural Sector}

Table 5.Long-run estimation for Agriculture normalized

\begin{tabular}{|c|c|}
\hline \multicolumn{2}{|c|}{ The endogenous variable is ATFP } \\
\hline Exogenous variables & Coefficients \\
\hline C & 10.79 \\
\hline FDI & -0.024 \\
& $(-5.22)$ \\
\hline PK & 0.544 \\
& $(3.26)$ \\
\hline HK & 0.286 \\
& $(4.63)$ \\
\hline TOP & 0.584 \\
& $(2.43)$ \\
\hline RER & -1.626 \\
& $(-7.21)$ \\
\hline INF & 0.056 \\
& $(7.25)$ \\
\hline
\end{tabular}

Source: Authors' computations through Eviews 10
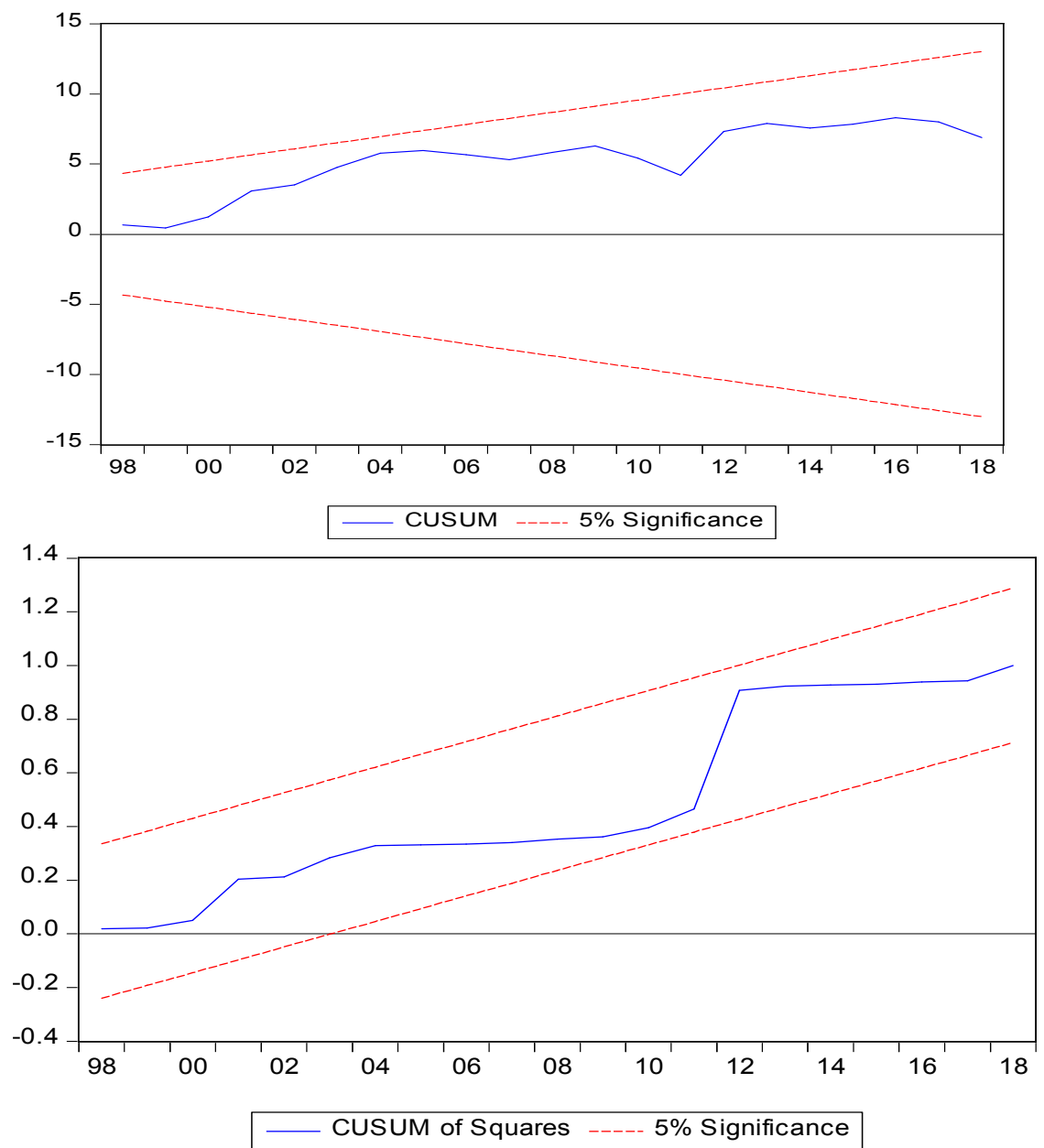

Figure 1: Agricultural sector model stability result

Long-run estimations revealed that FDI is negatively related to agricultural sector growth in Ivory Coast. The results indicated that USD 1 million (translated from -0.024) units increases FDI, decreases agricultural GDP by 0.024 . The studies have shown that because FDI inflows have a small effect on the sector the results 
tend to be insignificant. Alfaro et al. (2004) affirm that theories about the relationship between Foreign Direct Investments (FDI) and Growth are commonly developed for the manufactured industries. In comparison, a $1 \%$ increase in capital stock (physical capital) would result in a 0.54 increase in the sector's GDP. This has a significant impact on agriculture, as it is reliant on land input; thus, development and acquisition of land can significantly increase the sector's production. Côte d'Ivoire is willing to commit to concluding trade deals with nations such as the United States for the export of their agricultural products; thus, the agricultural sector's development is vital.

Empirical evidence indicates that open economies will grow faster than closed economies. Long-run results indicated that increasing the openness rate by a percentage point increases agricultural sector TFP by 0.58 . After 1998, Ivory Coast's trade increased significantly. The country produces and exports a variety of goods, including wool, cotton, fruits, and grains, to countries such as the Netherlands and the United Kingdom. These are the top three destinations for Ivory Coast's exports. The findings indicate that the real effective exchange rate has a longrun negative relationship with agricultural sector growth. In the long run, a $1 \%$ increase in the real effective exchange rate (real currency depreciation) reduces sector growth by 1.62 percent. A strong currency may reduce the sector's export competitiveness, but it will increase the value of imported goods and services. Balassa and Samuelson (1964) established unequivocally that there is a manifestly positive and significant relationship between real effective exchange rate appreciation and growth. Numerous empirical studies, such as Kalyoncu et al. (2008), support the hypothesis that depreciation reduces outputs and employments.

In addition, the VECM results indicated a significant long-run relationship between agricultural growth and inflation. In contrast to inflation versus growth theories, some evidence suggested that high inflation may actually be beneficial to economic growth. On the other hand, Keynes (1935) argued that some inflations are necessary to avoid the paradox of savings in the economy, which occurs when consumers' income increases faster than their consumption, reducing aggregate demand and ultimately resulting in economic growth. Due to the seasonal nature of agricultural productions, short-term disruptions will largely determine the sector's quantity supplied. As a result of rising prices, farmers may be tempted to increase production. As a result, the results indicate that a $1 \%$ increase in inflation would result in a 0.056 increasing trend in the sector's GDP.

Table 6. Speed adjustment and short-run results

\begin{tabular}{|c|c|}
\hline \multicolumn{2}{|c|}{ Agriculture model } \\
\hline Variable & Coefficient \\
\hline ATFP & $\begin{array}{c}-0.05 \\
(-1.49)\end{array}$ \\
\hline FDI & $\begin{array}{c}-1.23 \\
(-1.59)\end{array}$ \\
\hline PK & 0 \\
\hline HK & 0 \\
\hline TOP & 0 \\
\hline RER & -0.04 \\
& $(-1.66)$ \\
\hline INF & 0.36 \\
& $(4.14)$ \\
\hline
\end{tabular}

The purpose of speed adjustments is to demonstrate how variables adjust dynamically in the direction of long-run equilibrium. In the current study, short-run adjustments coefficients were restricted depending on their significant effects on long-run adjustments. The agricultural model predicted that the TFP would need to be corrected by approximately $5 \%$ per year to achieve balance. In the table 6 above, the negative sign indicates that the TFP will approach equilibrium. In a manner similar to the long run, the short run findings indicated that FDI has significant effects on agricultural TFP.

\section{Conclusion}

This research reveal the findings of the impact of FDI on the agricultural sector in Ivory Coast.We started with the results we got from the unit root tests of the Dickey-Fuller and Phillips-Perron. As a result, these tests tell us that the variables have not been stationary at levels, and become stationary from the first difference.

After the Unit Root tests, we had the estimation of VAR models and diagnostic tests.

These Tests were complete to ensure the models suitability. The Diagnostic tests affirm the robustness of residuals of the estimated VARs. In order to find the long-run relationships between our study variables, the cointegration tests have been conducted and it reveals the cointegration and the long-run relationship within variables.

Since there is a proof of cointegration, the VECM were estimated to determine the long- and short-runs dynamics. Taking into account our results, we find that FDI could have a negative impact on the agricultural 
sector. Further studies are suggest to understand the agricultural setor and help the productivity in that sector. Since Agriculture is the mainstay of GDP and economy in Ivory Coast, studies should be done into the

feasibility of channeling FDI towards the small-scale agricultural industry and with an aim to counter poverty.

\section{References}

Aitken, B., and Harrison, A. (1991), “Are there spillovers from foreign direct investment? Evidence from panel data for Venezuela", World Bank, Washington, DC Mimeo.

Alfaro, L., and Charlton, A. (2007), "Growth and the quality of foreign direct investment: is all FDI equal" HBS Finance Working Paper No. 07-072, Available at SSRN: https://ssrn.com/abstract=981163 or http://dx.doi.org/10.2139/ssrn.981163

Alfaro, L., Chanda, A., Kalemli-Ozcan, S., and Sayek, S. (2004), "FDI and economic growth: the role of local financial markets", Journal of international economics 64(1), 89-112.

Awunyo-Vitor, D., and Sackey, R. A. (2018), "Agricultural sector foreign direct investment and economic growth in Ghana", Journal of Innovation and Entrepreneurship 7(1), 1-15.

Balassa, B. (1964), "The purchasing-power parity doctrine: a reappraisal", Journal of political Economy 72(6), 584-596.

Blomström, M., Kokko, A., and Mucchielli, J. L. (2003), "The economics of foreign direct investment incentives", In Foreign direct investment in the real and financial sector of industrial countries (pp. 37-60). Springer, Berlin, Heidelberg.

Borensztein, E., De Gregorio, J., and Lee, J. W. (1998), "How does foreign direct investment affect economic growth?", Journal of international Economics 45(1), 115-135.

Dounamba, K. (2016), “An analysis on the Impact of Foreign Direct Investment (FDI) on Economic Growth of Underdeveloped African Countries: A case study on Mali”, Journal of Humanities and Social Science 21(9), $1-39$

Edeh, C. E., Eze, C. G., and Ugwuanyi, S. O. (2020), "Impact of foreign direct investment on the agricultural sector in Nigeria (1981-2017)", African Development Review 32(4), 551-564.

Enders, W. A. L. T. E. R. (2004), “Applied Econometric Time Series","2th Ed”. New York (US): University of Alabama.

Epaphra, M., and Mwakalasya, A. (2017), “Analysis of foreign direct investment, agricultural sector and economic growth in Tanzania", Modern Economy 8, 111-140.

Iddrisu, A. A., Immurana, M., and Halidu, B. O. (2015), "The impact of foreign direct investment (FDI) on the performance of the agricultural sector in Ghana", International Journal of Academic Research in Business and Social Sciences 5(7), 240-259.

Kalyoncu, H., Artan, S., Tezekici, S., and Ozturk, I. (2008), "Currency devaluation and output growth: an empirical evidence from OECD countries", International Research Journal of Finance and Economics 14(2), 232-238.

Keynes, J. M. (1935), 1982. "The Future of the Foreign Exchanges", In vol. 21 of The Collected Writings of John Maynard Keynes, edited by Donald Moggridge.

Klein, M., Aaron, C., and Hadjimichael, B. (2001), "Foreign Direct Investment and Poverty Reduction", World Bank Policy Research Working Paper.

Mazenda, A. (2014), "The effect of foreign direct investment on economic growth: Evidence from South Africa", Mediterranean Journal of Social Sciences, 5(10), 95-95.

Msuya, E. (2007), "The impact of foreign direct investment on agricultural productivity and poverty reduction in Tanzania", MPRA Paper, Kyoto University

Romer, P. (1993), "Idea gaps and object gaps in economic development”, Journal of monetary economics 32(3), 543-573.

Samuelson, P. A. (1964), "Theoretical notes on trade problems", The review of economics and statistics 145-154.

Yapatake, P. K., Li, S. J., and Abeid, R. A. (2017), "Military Expenditure, Export, FDI and Economic Performance in Cameroon (No. 17/002)", Centre de Recherche pour le DÃ @ veloppement Economique (CEREDEC). 